\title{
Türkiye’de Banka Ve Sigorta İşlemlerinden Kaynaklanan Uyuşmazlıkların Çözümünde Tahkim Uygulaması*
}

\author{
Derviş BOZTOSUN** \\ Selahattin $\mathrm{KOÇ}^{* * *}$ \\ Barıș AKSOY ${ }^{* * * *}$
}

\section{$\ddot{O Z E T}$}

Bu çalışmada İstanbul'da kurulan tahkim merkezi ile devletin hukuki müdahale aracı olarak oluşturacağı etkinin Türkiye'nin finansallașma sürecine olan etkileri incelenmektedir. Finans sektörünün yaklașı \%90'ı banka ve sigorta şirketlerinden oluştuğundan çalışmamızda banka ve sigorta şirketlerinin işlemlerinden kaynakl uyuşmazlıkların çözümünde tahkim uygulamasının gelișim düzeyi ele alınmaktadır. Türkiye Bankalar Birliği bünyesinde kurulan Bireysel Müsteri Hakem Heyetine 2014-2017 yılları arasında krediler, sigorta işlemleri, mevduat işlemleri, fatura ve diğer ödemelerle ilgili yapılan başvuru saylsı yıllar itibariyle sürekli azalmaktadır. Bireysel Müsteri Hakem Heyetine yapılan başvuruların müşteri lehine sonuçlandırma oranları da 2014 yılından itibaren sürekli azalmaktadır. Banka ve kredi kartları bașvuruları her yıl artmakta iken müsteri lehine sonuçlandırma oranı yıllar itibariyle azalmaktadır. Sigorta Tahkim Komisyonuna olan başvurular ise 2012 yllindan 2017 yllina kadar devamlı artıs göstermiștir. Sigorta Tahkim Komisyonuna başvuruların hızlı şekilde artması sigortacılık alanındaki uyuşmazlıkların çözümünde hakemlik kurumunun taraflarca benimsendiği ve başarılı bir şekilde uygulandı̆̆ı hakkinda genel olarak bilgi vermektedir.

Anahtar Kelimeler: Bankacılık Işlemleri, Sigortacılık Işslemleri, Alternatif Uyuşmazlık Çözümü, Tahkim, Bireysel Müşteri Hakem Heyeti, Sigorta Tahkim Komisyonu.

JEL Sinıflandirması: G21, G22, J52. \section{Turkey}

\section{ABSTRACT}

In this study, the effects of Istanbul Arbitration Centre and legal struggle of the state's on Turkey's process of financialization are examined. Since about $90 \%$ of the finance sector is composed of banks and insurance companies, the level of development of bank and insurance companies' arbitration in the resolution of disputes arising from their transactions is discussed in this study. The number of applications about loans, insurance transactions, deposit transactions, utility billing payment and other payments between 2014 and 2017 to the Customer Complaints Arbitration Committe founded within The Banks Association of Turkey has declined steadily in years. The rate of resulting in favor of customer of applications to The Banks Association of Turkey, Customer Complaints Arbitration Committe has declined consistently since 2014. While applications for bank and credit cards are increasing every year, the rate of resulting in favor of customer is declining over years. The applications for the Insurance Arbitration Commission have increased steadily from 2012 until 2017. The rapid increase in the number of applications to the Insurance Arbitration Commission provides general information about the successful application and adoption of the arbitration commission by the parties in the resolution of disputes in the field of insurance.

Keywords: Banking Transactions, Insurance Transactions, Alternative Dispute Resolution, Arbitration, Customer Complaints Arbitration Committee, Insurance Arbitration Commission.

Jel Classification: G21, G22, J52.

Makale Gönderim Tarihi: 03.10.2018

Makale Kabul Tarihi: 20.10.2018

Makale Türü: Derleme

\footnotetext{
* Bu çalışma 1. Uluslararası Bankacılık Kongresinde sözlü olarak sunulan “Türkiye'de Banka ve Sigortacılık İşlemlerinden Doğan Uyuşmazlıkların Çözümünde Tahkim Uygulamasının İncelenmesi” adlı tebliğin, alınan eleştiri ve katkılar doğrultusunda son şekli verilen halidir.

** Prof. Dr., Kayseri Üniversitesi, Uygulamalı Bilimler Fakültesi, dboztosun@erciyes.edu.tr, ORCID ID: 0000-0002-2656-2701.

*** Doç. Dr., Cumhuriyet Üniversitesi, İktisadi ve İdari Bilimler Fakültesi, skoc@cumhuriyet.edu.tr, ORCID ID: 0000-0003-4285-5632.

**** Öğr. Gör. Dr., Cumhuriyet Üniversitesi, İktisadi ve İdari Bilimler Fakültesi, baksoy@cumhuriyet.edu.tr, ORCID ID: 0000-0002-1090-5693.
} 


\section{GíRİş}

Hukukun ekonomideki rolü, piyasanın düzenli çalışmasını ve gelişmesini sağlayacak olan yasal çerçeveyi oluşturmaktır. Diğer yandan, ekonomik yaşamı düzenleyen hukuk kurallarının, ekonominin dinamikleri ve gerçekleri ile bağdaşması gerekmektedir (Baykal, 2008: 78). Yarg1 yetkisiyle, hukuk düzeninin korunması ve gerçekleştirilmesi amaçlanmaktadır. Egemenlik anlayışının bir gereği olarak yargılama hak ve yetkisi devlet tekelinde bulunmakta ve hukuki uyuşmazlıklar devlet mahkemelerinde çözüme kavuşturulmakta olup tahkim bu kuralın istisnasını oluşturmaktadır. Hakkı ihlal edilen kişi, devlet mahkemelerinin dışında oluşturulan tahkim yoluna başvurabilmektedir. Tahkim, kural olarak ihtiyaridir. Hukuk Usulü Muhakemeleri Kanunu'nda düzenlenen tahkim yolu; "ihtiyari tahkim"dir (Bacanlı, 2016: 77).

Günümüzde devletin hukuk kurallarını ihdası ve uygulanmasındaki tekeli bazı alanlarda yerini tarafların iradelerinin uyuşmazlığın çözümünde aktif rol oynadığı alternatif uyuşmazlık çözümlerine bıraktığı söylenebilir (Kayıhan ve Eski, 2015: 91). Tahkim, tarafların anlaşmazlıkları ile ilgili bir karar vermek üzere hakem denilen, bir veya daha fazla kişiye anlaşmazlıklarının götürüldüğü bir anlaşmazlık çözüm mekanizmasıdır (Zhu, 2013: 150). Tahkim, devlet mahkemeleri yargılamasının yerine ikame edilen ve hakemlerin maddi olayı belirli bir hukuki kalıba göre hüküm vermeleri ile kesin hüküm durumuna gelen temyize ve cebri icraya elverişli bir yargısal yoldur (Bulur, 2007: 32).

Belli konulardaki uyuşmazlıklarda alternatif çözüm yöntemlerine $A B D$ ve Avrupa ülkelerinde yaygın bir şekilde başvurulmaktadır (Dağlı ve Çakır, 2009: 36). ABD'de finansal uyuşmazlıklarda alternatif çözüm yöntemleri genellikle uyuşmazlığın tarafı olarak faaliyet gösteren kişi ve kurumların üye olduğu öz düzenleyici kuruluşlar tarafından sağlanmaktadır. Avrupa ülkelerindeki uygulamalarda ise alternatif çözüm yöntemleri; genellikle ticaret odaları, mesleki birlikler ve menkul kıymet ve emtia borsaları nezdinde örgütlenmiş olan tahkim merkezleri tarafindan yürütülmektedir (Dağlı ve Çakır, 2009: 40).

Tahkim ülkemizde giderek bir uzmanlık alanı haline gelmektedir. Uyuşmazlıkların kısa sürede çözüme kavuşturulması, adli tatilde uyuşmazlıkların çözülmesi için tahkim süreçlerinin devam etmesi, mahkemede davalaşmaya oranla daha ucuza mal olması, tahkime götürülen dava sayısının az olması, tahkim sürecinde tarafların bilgilerinin gizli olması ve kredi veren kuruluşların uyuşmazlığın tahkim yoluyla çözülmesine yönelik talepleri ülkemizde tahkim müessesesinin hızla gelişmesinin nedenleri arasında sayılabilir (Bacanlı, 2016: 78). Ülkemizde yargı sisteminin ağır işlemesi ve finansal konularda mahkemelerin yeterince ihtisaslaşmamış olması ülkemiz açısından bir dezavantaj olarak görülmektedir. Böyle bir ortamda tahkimin etkin ve güvenilir bir uyuşmazlık çözüm müessesesi olarak işler hale getirilmesiyle İstanbul'un farklı ülkelerde bulunan Uluslararası Finans Merkezi pazarından pay almasına yönelik çalışmalarda önemli bir rol oynayacağı düşünülmektedir (Dağlı ve Çakır, 2009: 28). Türkiye'de en önemli eksikliklerden biri finansal alanda ihtisaslaşmış mahkemelerin bulunmamasıdır (Gündoğdu ve Dizman, 2013:10). Türkiye'de yargı sisteminde çeşitli sorunların bulunduğu kamuoyunca 
bilinmektedir. Dava süreçlerinin uzaması ve etkin bir şekilde çözüme kavuşturulamaması yargı sisteminin eksiklikleri arasındadır (Şahin, 2013: 137).

Ülkemizde sermaye piyasası işlemlerinden doğan uyuşmazlıklarda tarafların yargıya başvuru hakları saklı kalmak üzere, yatırımcıların borsa işlemleri nedeniyle borsa üyeleri ile olan uyuşmazlıklar Borsa İstanbul'da (BIST) çözümlenir. Başvuru üzerine, süreç tamamlandıktan sonra, uyuşmazlık borsa yönetim kurulu tarafından karara bağlanır. Yatırımcıların, Vadeli İşlem ve Opsiyon Borsası (VOB) üyesi olan banka ve aracı kurumlarla ilgili şikâyetleri VOB Yönetim Kurulu tarafından çözülür. Ayrıca, her zaman için mahkemeye başvurulabilir (Aksoy vd. 2017: 1872-1873). Sermaye piyasası işlemleri kaynaklı uyuşmazlıkların çözüm yerinin ilgili borsa yönetimleri olması nedeniyle bu çalışmada banka ve sigortacılık işlemlerinden kaynaklanan uyuşmazlıkların çözüme kavuşturulmasında alternatif uyuşmazlık çözüm yollarının ne düzeyde gelişmiş olduğuna yer verilmektedir. Şekil 1'de, bilanço büyüklügü göz önüne alındığında finans sektörünün yaklaşık \%90'1 banka ve sigorta şirketlerinden oluştuğundan çalışmamızda banka ve sigorta şirketlerinin işlemleri sonucunda meydana gelen uyuşmazlıkların çözümünde etkinlik, hız ve doğru karar vermenin önemi daha iyi anlaşılacaktır.

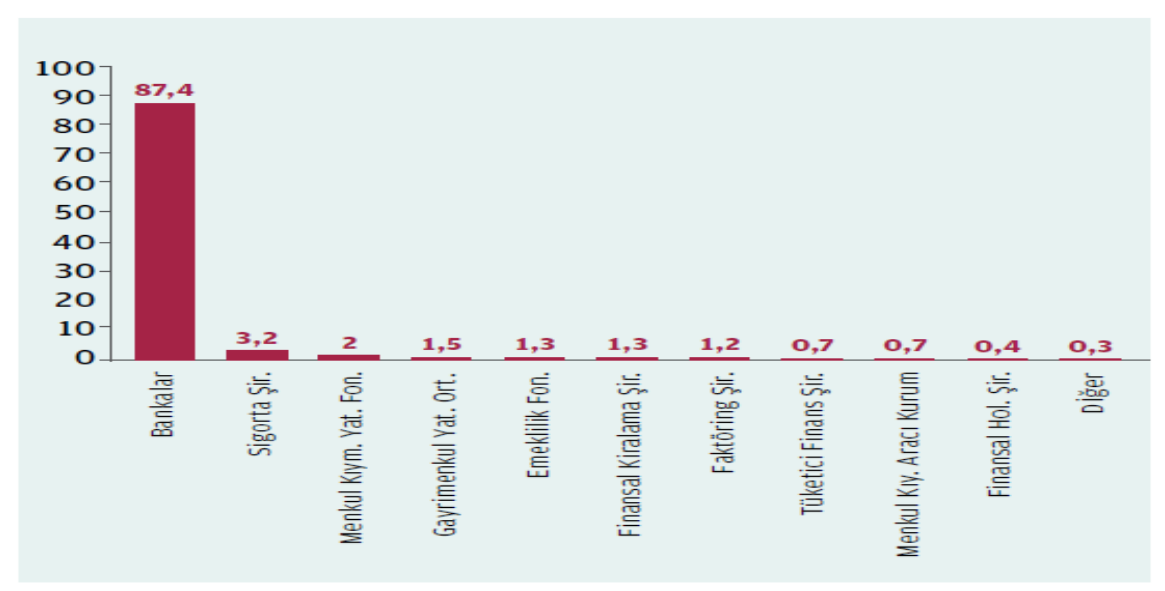

Kaynak: http://www.tcmb.gov.tr (Erişim Tarihi: 18.05.2017)

Şekil 1. Finansal Sektörün Bilanço Büyüklüğünün Dağılımı (\%) (2014 Y11ı)

Çalışmanın birinci bölümünde giriş, ikinci bölümde Türkiye'de finansal kurumların işlemlerinden kaynaklanan uyuşmazlıklarda tahkim uygulaması, üçüncü bölümde Türkiye'de bankacılık işlemlerinden doğan uyuşmazlıkların çözümünde tahkim uygulaması, dördüncü bölümde Türkiye'de sigortacılık işlemlerinden doğan uyuşmazlıkların çözümünde tahkim uygulaması ve beşinci bölümde sonuç yer almaktadir. 


\section{TÜRKIYYE'DE FINANSAL KURUMLARIN ISSLEMLERINDEN KAYNAKLANAN UYUŞMAZLIKLARDA TAHKIM UYGULAMASI}

Finansal "alternatif uyuşmazlık çözümü” (ADR, Alternative Dispute Resolution) sistemi, müşterilerin finansal hizmet sağlayıcılara karşı şikâyetlerine çözümler üreten ve adli işlemler yerine belirlenmiş anlaşmazlık çözme kurumları tarafından ADR yöntemleri aracılığıyla müşteriler-yatırımcılar ve finansal hizmet sunucuları arasındaki çatışmaları çözen bir sistemi ifade etmektedir (Yanase, 2013: 35). Tahkim ve arabuluculuk yönteminin devlet mahkemelerinde dava açmaya uygun bir alternatif olup olmadığı, borç tartışmasının doğasına bağlıdır (Golann, 1989: 4-5). Tahkim yöntemi, anlaşmazlıkları çözüme kavuşturmak için mahkemeye göre çok daha hızlı ve ucuz bir yol sunmaktadır. Bu nedenle hem tüketiciler hem de finansal servis sağlayıcıları tarafından sıklıkla kullanılmaktadır (Petrauskas ve Gasiūnaitè, 2012: 180181).

Finansal kurumlar, mahkemelerde açılan davalar için önemli miktarda dava giderleri ve tazminat ödemek yerine tahkim yoluyla daha düşük tutar ödeyerek büyük tasarruflarda bulunmaktadırlar. Ayrıca dava sonucunun kamuoyuyla paylaşılması durumunda kurumları aleyhine verilen kararların yayınlanmasının yıpratıcı etkisinden de kurtulmuş olmaktadırlar (Budnitz, 1995: 269-271). Hakemlerin kararlarını açıklayan yazılı görüş bildirmeleri şart değildir. Bu nedenle, mali kurumlar, dava sonucu kendi kurumları aleyhine verilen bir kararın başkalarını aynı gerekçelerle dava açmaya teşvik edeceği gibi konularda endişe etmeyecektir. Finansal bir kurum aleyhine olan bir kararın kamuoyuyla paylaşılmasının bir finansal kurum için iki zararlı sonuçları vardır. Birincisi, kurumun kamu imajı ciddi ölçüde olumsuz etkilenebilir, ikinci olarak, daha önce açılmış ve ilgili finansal kurumun aleyhine sonuçlanmış bir karar, tüketicileri ilgili finans kurumuna karşı dava açmaya teşvik edebilir. (Budnitz, 1995: 271-272).

Tahkimin, günümüzde ABD ve Avrupa ülkelerinde sık kullanılan diğer yarg1 dışı alternatif uyuşmazlık çözüm yollarından farklı yönleri vardır. Tahkim, sadece tarafların anlaşmazlıklarını mahkeme dışında çözüme kavuşturmaları için değil, aynı zamanda kararın taraflar açısından bağlayıcılığını da beraberinde getirmektedir. Aksine, ne arabuluculuk ne de uzlaşma yasal olarak bağlayıcı değildir (Park, 1998: 217). Hakemler kararlarını yetkili ve görevli mahkeme kalemine sunarlar. Kararın mahkeme tarafından taraflara tebliğ tarihinden itibaren taraflar kararı temyiz edebilir. Temyiz sonunda hakemlerin verdikleri karar onanırsa kesinleşmiş olur. Süresi içinde karar temyiz edilmezse karar kesinleşir ${ }^{1}$. Hakem kararları ancak kesinleştikten sonra icra edilebildiği için kararın kesinleşmesi önemlidir (Dağlı ve Çakır, 2009: 32).

\footnotetext{
1 "Dava, taraflar arasındaki 01.06.2009 tarihli sözleşmenin uygulanmasıyla ilgili doğan uyuşmazlığın Türsab Tahkim Kurulu'nca veya mahkemece çözümlenmesi istemine ilişkindir. Sözleşmenin 7. maddesinde taraflar arasında doğacak uyuşmazlıkların çözümü için tahkim şartı öngörülmüş, bu kapsamda taraflarca 3 kişilik hakem heyetine gidilmiş ise de, hakem heyetince, HMK'nun 421/f.3 bendi uyarınca tahkim koşulu bozulduğundan HMK'nun 435/1.c. bendi uyarınca tahkim yargılamasının imkansız hale geldiğine ve yargılamanın sona erdiğine karar verilmiştir. Taraflarca işbu hakem kararının iptali yoluna gidilmemesi nedeniyle hakem kararı da kesinleşmiştir. Bu durumda, sözleşmedeki tahkim şartının hükümsüz kaldığı ve 6100 sayılı HMK'nun 413/1. maddesi uyarınca davalının tahkim itirazının reddi gerektiği gözetilerek, davanın esasına girilerek inceleme ve değerlendirme yapılması gerekirken,
} 
Türkiye'de alternatif uyuşmazlık çözüm yöntemleri konusunda çok gelişmiş bir uygulama olduğu söylenemez. Bunun en önemli nedeni alternatif uyuşmazlık çözüm yöntemlerinin ve hatta tahkimin, adalet uygulayıcılarının ciddi bir kısmı tarafından yerel mahkeme yargısının rakibi olarak görülmesi ve onun etkinliğini azaltacağı yönündeki düşüncelerdir (Perçin, 2011: 190). Alternatif uyuşmazlık çözüm yolları, yargı ile rekabet içinde bulunan bir yöntem değildir. Sözü edilen yolların asıl hedefi, küçük çaplı ve kamu düzenini ilgilendirmeyen uyuşmazlıkların, adli bir soruna dönüşmeden çözümünü sağlamaktır (Tanrıver, 2006: 152). Tahkim anlaşmasında, temel ilişkiyi kuran sözleşmede bir tahkim şartına yer verilebileceği gibi ayrı bir tahkim sözleşmesi yapılarak da gerçekleşebilir (Ulusoy, 2014: 203-204).

Türkiye, "Milletlerarası Tahkim Kanunu ve Hukuk Muhakemeleri Kanunu"nun yanı sıra Milletlerarası Ticarî Hakemlik konusundaki 1961 tarihli Cenevre-Avrupa Sözleşmesi dâhil olmak üzere tahkim alanındaki milletlerarası sözleşmelerin neredeyse tamamına taraftır. Bu konudaki en önemli sözleşme "Yabancı Hakem Kararlarının Tanınması ve Tenfizi ${ }^{2}$ Hakkındaki 1958 tarihli New York Sözleşmesi”ddir (Akınc1, 2013: 87). Milletlerarası ticari tahkimin yanı sıra, Türkiye yatırım uyuşmazlıkları alanında son derece önemli çok taraflı ve iki taraflı milletlerarası anlaşmalara taraftır. Bunlar arasında en önemlisi "Devletler ve Diğer Devletlerin Vatandaşları Arasındaki Yatırım Uyuşmazlıklarının Çözümlenmesi Hakkında Sözleşme, ICSID.”dir.

İstanbul Tahkim Merkezi, kurumsal tahkim hizmeti sunmak amaciyla kurulmuş, bağımsız bir tahkim kurumudur. Ülkemizde tahkim merkezi kuruluşu konusunda gerekli mevzuat oluşturulmuş, Tahkim Merkezi 20.11.2014 tarihinde kabul edilen ve 29.11.2014 tarihinde Resmi Gazetede yayınlanan 6570 sayılı Kanun ile kurulmuştur. Bu Kanunun amacı, yabancılık unsuru taşıyanlar da dâhil olmak üzere uyuşmazlıkların tahkim veya alternatif uyuşmazlık çözüm yöntemleriyle çözülmesini sağlamak üzere İstanbul Tahkim Merkezinin kurulması ile Merkezin teşkilat ve faaliyetlerine ilişkin usul ve esasları düzenlemektir (Bacanl1, 2016: 75-76).

Türkiye'de tahkim sistemi özel hukuk alanında ilk olarak bankacılık, sigortacılık ve sermaye piyasasında uygulanmaya başlamıştır. Tablo 1'de hukuk mahkemelerinde açılan davaların dava türlerine göre dağılımı adet bazında verilmektedir. 2017 ve 2018 yılları verileri çalışmanın son güncellendiği (07.08.2018) tarihte yayınlanmadığından tabloda yer almamaktadır.

mahkemece yazılı gerekçelerle davanın reddine karar verilmesi doğru olmamış, bozmayı gerektirmiştir”. (Yargitay 11. H.D.’nin 06.12.2017 Tarih, 2016/4898 Esas ve 2017/6952 Karar Sayılı İlamı).

${ }^{2}$ Yabancı ülkede alınan icrai kabiliyeti haiz bir mahkeme kararının Türkiye'de yerine getirilmesine tenfiz adi verilir. 
Tablo 1. Hukuk Mahkemelerinde Açılan Davaların Dava Türlerine Göre Dağılımı (2006-2016 Y1lları, Adet)

\begin{tabular}{|c|c|c|c|c|c|c|c|}
\hline Yıllar & Alacak & $\begin{array}{c}\text { Hakem } \\
\text { Tayini }\end{array}$ & $\begin{array}{c}\text { Tüketici } \\
\text { Hakem Kurulu } \\
\text { Kararına İtiraz }\end{array}$ & $\begin{array}{c}\text { Kredi } \\
\text { Kartı }\end{array}$ & Sigorta & Tahkim & $\begin{array}{c}\text { Çek } \\
\text { Iptali }\end{array}$ \\
\hline 2006 & 95094 & 229 & 3233 & 87 & 24 & 6 & 598 \\
\hline 2007 & 110274 & 2888 & 4516 & 75 & 325 & 16 & 2450 \\
\hline 2008 & 27595 & 688 & 1555 & 81 & 215 & 33 & 829 \\
\hline 2009 & 117468 & 139 & 1550 & 283 & 73 & 117 & 17862 \\
\hline 2010 & 111073 & 164 & 3849 & 246 & 85 & 362 & 18089 \\
\hline 2011 & 123928 & 366 & 2523 & 109 & 60 & 623 & 15510 \\
\hline 2012 & 92151 & 828 & 7767 & 243 & 50 & 1770 & 15569 \\
\hline 2013 & 28851 & 447 & 11142 & 418 & 11 & 1284 & 14797 \\
\hline 2014 & 50534 & 268 & 28492 & 710 & 16 & 85 & 16701 \\
\hline 2015 & 13779 & 56 & 49027 & 301 & 10 & 58 & 16181 \\
\hline 2016 & 10101 & 22 & 35705 & 196 & 4 & 61 & 15827 \\
\hline
\end{tabular}

oluşturulmuş̧ur. (Erişim Tarihi: 10.06.2017)

Kanun koyucu bazı uyuşmazlıklar için tahkimi zorunlu tutarken, bazı uyuşmazlıklar için uyuşmazlığın taraflarına devlet mahkemeleri veya alternatif uyuşmazlık çözüm yolları arasında tercih yapma hakkı tanımıştır. Tarafların, uyuşmazlığın çözümü için tahkime başvurmada serbest olup olmamalarına göre tahkim zorunlu ve ihtiyari olmak üzere ikiye ayrilır. Zorunlu tahkimde (kanuni hakemde) uyuşmazlığın çözümü için tarafların iradelerine bakılmaksızın tahkime gitme zorunluluğu vardır. Belirli şartlar gerçekleştiğinde uyuşmazlığın çözümü kanunla tespit edilmiş hakem veya hakem kurulu tarafindan yapılacaktır. Tüketici hakem heyetleri zorunlu tahkime örnek olarak verilebilir. İhtiyari tahkimde ise taraflar uyuşmazlıklarını tahkim aracılığıyla çözüp çözmeme, hakem veya hakemleri seçme, hakemlerin çözeceği uyuşmazlıkları tespit gibi konularda serbest hareket ederler. İhtiyari tahkimde taraflar tahkime başvurmakta serbest olsalar da tahkimin kararıyla bağlıdırlar (Bacanlı, 2016: 78-79). Kısaca taraflar, tahkim sözleşmesinde veya tahkim şartında kararlaştırdıkları tahkim yönteminde, hakem veya hakem kurulu tarafindan verilecek kararları başlangıçta kabul etmiş olmaktadırlar (Dağlı ve Çakır, 2009: 30). Türk hukukunda hakem kararlarının iptali incelediğinde iptal sebeplerinin başında tahkim şartının geçerliliği ile ilgili konular yer almaktadır. Bunlar; mahkeme ve hakemin aynı anda yetkilendirilmesi (seçimlik tahkim şartı), yetkili olmayan kişilerin imzaladıkları tahkim sözleşmeleri, tahkim şartına taraf olmayan şirketlerin dava edilmesi ${ }^{3}$ gibi durumlarda mahkemeler

\footnotetext{
3 “Tahkim şartı bir sözleşmenin taraflarının bu sözleşmeden kaynaklanabilecek uyuşmazlıkların çözümü hakeme bırakmak hususunda yaptıkları bir anlaşmadır. Tahkim şartını içeren sözleşme davacı şirket ile davalı M... Enerji Tic. AŞ. arasında imzalanmıştır. Bu nedenle tahkim şartının sözleşmenin tarafı olmayan davalı banka M.... Corp.'a teşmili düşünülemez. Çünkü uyuşmazlıkların mahkemelerde görülmesi esastır. Tahkim sözleşmesi istisnai bir nitelikte olup sözleşmenin taraflarını bağlar. Aksi düşünce Anayasanın 9. maddesinde teminat altına alınan yargı yetkisinin bağımsız mahkemelerde kullanılacağına ilişkin kurala ve tabii hakimde yargılama hakkına aykırı düşer. Yukarıda açıklanan nedenlerle tahkim şartı sözleşmesinin tarafı olmayan davalı I... Bankası ve M Corp.'a teşmil edilemeyeceğinden adı geçenler hakkındaki davanın esasının incelenip uygun sonuç dairesinde bir karar verilmesi gerekirken yazılı
} 
hakem kararının iptaline karar vermektedirler. Türk hukukunda tahkim anlaşması için genel vekâletname yeterli olmayıp, özel yetki aranmaktadır (Bacanlı, 2016: 87).

\section{TÜRKIYE'DE BANKACILIK IŞLEMLERINDEN DOĞAN UYUŞMAZLIKLARIN ÇÖZÜMÜNDE TAHKIM UYGULAMASI}

Finansal kurumlar giderek artan şekilde tüketicilerin mahkemelerde dava açmak yerine uyuşmazlıkların tahkim yoluyla çözülmesini istemektedirler. Ayrıca finansal kurumlar, aşırı maliyetlerin ve dava gecikmelerinin azaltılmasına yardımcı olacak alternatif bir yol olarak tahkimin kullanılmasını istemektedirler. Tahkim programlarının uygulanmasıyla beraber öncelikle borç verme ile ilgili davalar ve cezai tazminat talep davalarından kaçınılması amaçlanmıştır(Budnitz, 1995: 268).

Bazı ülkelerde bankalar, borç vermeyle ilgili davalarda gelecekteki zararları önlemek için başlıca stratejileri olarak tahkimi kullanmak istediklerini açıklamaktadırlar. Ancak, hazırladıkları tahkim sözleşmelerinin incelenmesi sonucu bu kurumların, konu itibariyle bu tür davalardan çok daha fazlasında tahkimi kullanmaya karar verdiklerini göstermektedir. Bu kurumlar, hemen hemen her uyuşmazlık türünde çözüm olarak ya da en azından bir alternatif çözüm olarak tahkime katılmaya karar vermektedirler (Budnitz, 1995: 271-272). Banka ve sigorta şirketleri gibi belirli sektörlerce tayin edilen müşteri ombudsmanlarının kararları, programa üye olan şirketler için bağlayıcı olmaktadır. Uyuşmazlığın tarafı olan şirketler alınan karara uymazlarsa, kararın yayımlanması veya şirketlerin üye oldukları ticarî sistemlerden ihraç edilmeleri mümkün olabilmektedir (Özbek, 2007: 306).

Bankacılık faaliyetleri içerisinde banka ve finans kuruluşları ile tüketiciler arasında çeşitli hukukî işlemler yapılmaktadır ${ }^{4}$. Tüketici işlemi niteliğindeki bu hukukî işlemlere istinaden banka ve finans kuruluşları, yaptıkları bu işlemler karşıllı̆ında bir takım ücret ve masraflar istemektedirler (Uyumaz ve Akdağ, 2016: 423). 6502 saylı Kanun ve bu Kanuna dayanılarak çıkarılan Finansal Tüketicilerden Alınacak Ücretlere İlişkin Usûl ve Esaslar Hakkında Yönetmelikle birlikte, bankacılık işlemlerinden alınan masraf ve ücretlere ilişkin olarak önemli düzenlemeler yapılmıştır (Uyumaz ve Akdă̆, 2016: 456). 4077 Sayılı Tüketicinin Korunması Hakkındaki Kanun'un 22. maddesine göre, değeri belirli bir parasal sınırın ${ }^{5}$ altındaki uyuşmazlıkların öncelikle Tüketici Sorunları Hakem Heyeti'ne götürülmesi zorunluluğu bulunmaktadır. Bu uyuşmazlıklarda hakem heyetinin vereceği karar tarafları bağlamaktadır (Perçin, 2011: 193). TKHK'nın 68 inci maddesinin ilk fikrasında uyuşmazlık konusu miktar

şekilde uyuşmazlığın tahkime tabii olduğu gerekçesiyle görevsizlik kararı verilmesi usul ve yasaya aykırıdır”. (Yargitay 19. H.D.'nin 11.03.2004 Tarih, 2003/2654 Esas ve 2004/2603 Karar Sayılı İlamı).

4 "Davacının kimsenin bilmemesi gereken ve korumakla yükümlü olduğu şifre, parola gibi kişisel bilgilerini koruyamadığı, bu konudaki özen yükümlülüğünü ihmal ettiği sabit olmadığı sürece davac1 müşteri bankada bulunan paranın internet bankacılığı yoluyla başka hesaba aktarılmasından dolayı sorumlu tutulamaz. Mahkemece bu yönler gözetilerek bir karar verilmesi gerekirken davacının da kusurlu bulunduğu kabul edilerek yazılı şekilde hüküm kurulmasında isabet görülmemiştir”. (Yargıtay 19.H.D.'nin 23.02.2011Tarih, 2011/481 Esas ve 2011/2326 Karar Sayılı İlamı).

${ }^{5}$ Söz konusu parasal sınır 01.01.2012 tarihinden itibaren geçerli olmak üzere 1.161,67 TL, Büyükşehir statüsünde bulunan illerde faaliyet gösteren il hakem heyetleri bakımından ise 3.032,65 TL'dir. 
bakımından, değeri iki bin Türk Lirasının altında bulunan uyuşmazlıklarda ilçe tüketici hakem heyetlerine, üç bin Türk Lirasının altında bulunan uyuşmazlıklarda il tüketici hakem heyetlerine, büyükşehir statüsünde bulunan illerde ise iki bin Türk Lirası ile üç bin Türk Lirası arasındaki uyuşmazlıklarda il tüketici hakem heyetlerine başvuru zorunludur (Uyumaz ve Akdağ, 2016: 451). Bu değerlerin üzerindeki uyuşmazlıklar için tüketici hakem heyetlerine başvuru yapılamaz (TKHK.m.68/I).

Bireysel Müşteri Hakem Heyeti, bankacılık hizmetleriyle ilgili olarak, (mevduat hesapları, tüketici kredileri, kartlar, vb.) tüketici-müşteri ve banka arasındaki uyuşmazlıkların değerlendirilmesi için başvurulabilecek, Türkiye Bankalar Birliği (TBB) bünyesinde kurulmuş bir heyettir. Bu heyetin amacı, TBB üyesi bankalar ile bireysel müşterileri arasındaki anlaşmazlıkları adil ve tarafsız bir şekilde incelemek ve taraflar arasında uzlaşı sağlamaktır. Hakem heyetinin faaliyetleri, sadece bireysel bankacılık işlemlerini kapsamakta ve gerçek kişilerin başvuruları değerlendirmeye alınmaktadır (Türkiye Bankalar Birliği, 2018).

Tablo 2'de 2012-2017 yılları arasında bankalara doğrudan yapılan başvuruların konularına göre dağılımı verilmektedir.

Tablo 2. 2012-2017 Yılları Arasında Bankalara Doğrudan Yapılan Başvuruların Konularına Göre Dağılımı (1.000 adet)

\begin{tabular}{|c|c|c|c|c|c|}
\hline Yıllar & Krediler & $\begin{array}{c}\text { Banka ve } \\
\text { Kredi Kartları }\end{array}$ & $\begin{array}{c}\text { Alternatif } \\
\text { Dağıtım } \\
\text { Kanalları }\end{array}$ & $\begin{array}{c}\text { Kredili } \\
\text { Mevduat Hesap } \\
\text { İşlemleri }\end{array}$ & $\begin{array}{c}\text { Sigorta } \\
\text { İşlemleri }\end{array}$ \\
\hline $\mathbf{2 0 1 2}$ & 315 & 1.985 & 388 & 52 & 61 \\
\hline $\mathbf{2 0 1 3}$ & 423 & 1.714 & 434 & 41 & 58 \\
\hline $\mathbf{2 0 1 4}$ & 960 & 2.312 & 542 & 58 & 85 \\
\hline $\mathbf{2 0 1 5}$ & 365 & 1.466 & 490 & 26 & 74 \\
\hline $\mathbf{2 0 1 6}$ & 125 & 1.484 & 527 & 19 & 36 \\
\hline $\mathbf{2 0 1 7}$ & 73 & 1.152 & 623 & 123 & 17 \\
\hline & Mevduat & $\begin{array}{c}\text { Tüm Fatura } \\
\text { ve Diğer } \\
\text { Ödemeler }\end{array}$ & $\begin{array}{c}\text { Yatırım Ürün } \\
\text { ve Hizmetleri }\end{array}$ & Diğer & Toplam \\
\hline $\mathbf{2 0 1 2}$ & 261 & 42 & 18 & 225 & 3352 \\
\hline $\mathbf{2 0 1 3}$ & 325 & 59 & 14 & 283 & 3351 \\
\hline $\mathbf{2 0 1 4}$ & 381 & 46 & 13 & - & 4397 \\
\hline $\mathbf{2 0 1 5}$ & 370 & 36 & 10 & - & 2837 \\
\hline $\mathbf{2 0 1 6}$ & 169 & 26 & 9 & - & 2395 \\
\hline $\mathbf{2 0 1 7}$ & 36 & 29 & 11 & - & 2.063 \\
\hline
\end{tabular}

Kaynak: Türkiye Bankalar Birliği, Bireysel Müşteri Hakem Heyeti Ylllık Faaliyet Raporu, (https://www.tbb.org.tr/tr, Erişim Tarihi: 02.08.2018)

Hakem heyetine yapılacak başvurularda anlaşmazlığa konu olay, başvuru tarihi itibariyle en çok iki yıl eski tarihli olmalıdır. Talep ile ilgili hakem heyetine başvuru yapmadan önce bankaya yapılan başvurunun banka tarafindan cevaplama süresi 30 gündür. Kredi kartlarıyla ilgili başvurularda ise bu süre 20 gündür. Hakem Heyetinin sunduğu hizmetler ücretsizdir. Heyetin vereceği kararlara bankalar, 3.069 TL'ye kadar uymak zorundadırlar. Bu tutar 2018 yılı için geçerli olup, her sene Ocak ayında Türkiye 
İstatistik Kurumu tarafından yayımlanan yıllık tüketici fiyat endeksi değişim oranında arttırılır (Türkiye Bankalar Birliği, 2018).

Başvuru konusuna göre, sekretarya tarafından kabul edilen başvurular aşağıdaki dört heyetten birine yönlendirilir. Yönlendirilecek heyetler şunlardır:

- $\quad$ Banka Kartları ve Kredi Kartları Bireysel Müşteri Hakem Heyeti

- $\quad$ Tüketici Kredileri Bireysel Müşteri Hakem Heyeti

- $\quad$ Sigortacilık İşlemleri Bireysel Müşteri Hakem Heyeti

- Diğer Bankacılık Ürün ve Hizmetleri Bireysel Müşteri Hakem Heyeti

(Birinci, ikinci ve üçüncü madde dışında kalan ürün ve hizmetlerle ilgili)

Bazı hukukçular alternatif uyuşmazlık çözümünü (ADR) sözleşmeden doğan uyuşmazlıkların çözümü için uzun bir süre davadan üstün bir yöntem olarak tanıtmışlardır. Bazı avukatlar tahkimin davadan daha uygun bir süreç olduğunu iddia etmektedirler. Tahkim davaya oranla daha basit usul ve kanıtlayıcı kurallara sahiptir ve tartışmalı tarafların anlaşmazlıklarını çözme konusunda davaya göre daha az düşmanca bir yöntem olduğu açıktır. Aslında, tahkim anlaşmazlıkların çözümünde, özellikle işletmeler gibi eşit pazarlık gücü olan taraflar arasında çok etkili bir yöntem olabilir. Anlaşmazlık öncesi tahkim, bir sözleşmeye giren tarafların, özel hâkimlerle tek bir duruşmayı kabul ederek dava açmayı reddettiği bir tür ADR'dir. Bugün, birçok tüketici sözleşmesi, bir tüketici ile mal ve hizmetlerin satışı veya kiralanması için bir tahkim şartı içermektedir. Bununla birlikte, tüketiciler bir ticari işletme ile sözleşme imzaladıklarında, çoğu zaman sözleşmelerinin bir tahkim şartı içerdiğinin farkında değildirler. Uyuşmazlığın tahkim ile çözümleneceğine yönelik madde, postayla sipariş edilen bir ürünle birlikte gönderilen ya da bir hizmet sözleşmesinin arka yüzüne basılmış formun içerisinde yer almaktadır. Ortalama dikkate sahip bir tüketici, tahkim şartının dilini dahi anlayamayabilir (Scarpino, 2002: 680).

Tablo 3'de 2012-2017 yıllarında gündeme alınan başvuruların müşteri lehine sonuçlanma oranı verilmektedir. Tablo 3 incelendiğinde banka ve kredi kartlarından kaynaklanan uyuşmazlık başvuruları hariç diğer tüm ürün ve hizmet grupları için 20152017 yıllarında müşteri lehine sonuçlanma oranında azalma görülmektedir. Aynı şekilde banka ve kredi kartı başvuruları hariç şikayet ile ilgili "Bankanın Talebi Karşılaması Sonucunda Gündemden Çıkarılan" başvuru sayısının azalması dikkat çekicidir. Bu sonuçlar hakem heyetinin oluşturulmasında TBB üyesi banka temsilcilerinin sayısı ve uzmanlık düzeyi, konuya objektif bakılıp bakılmadığının incelenmesinin yanı sıra bankalardan hizmet alan müşteri/tüketicilerinde finansal okuryazarlık düzeyinin etkili olup olmadığı ayrıca incelenmelidir. Heyetin oluşumuna bakıldığında heyetlerde, ikisi Bankacilık Düzenleme ve Denetleme Kurumu temsilcisi üçü de TBB'nin Heyet üyesi olarak belirlediği bankalar tarafından görevlendirilen toplam beş temsilciden oluşur. Birlik tarafından üye olarak seçilen bankalar birer temsilci bildirirler. Heyet temsilcileri TBB üyesi bankaların gösterdikleri adaylar arasından TBB Yönetim Kurulu tarafından seçilir(TürkiyeBankalarBirliği,2017). 
Tablo 3. 2012-2017 Yıllarında Bireysel Müşteri Hakem Heyetinde Gündeme Alınan Başvuruların Müşteri Lehine Sonuçlanma Oranı

\begin{tabular}{|c|c|c|c|c|c|c|c|c|}
\hline $\begin{array}{c}\text { Ürün ve Hizmet } \\
\text { Grupları }\end{array}$ & Yillar & $\begin{array}{c}\text { Alınan Toplam } \\
\text { Başvuru }\end{array}$ & $\begin{array}{l}\text { Gündeme } \\
\text { Alınmayan }\end{array}$ & $\begin{array}{l}\text { Gündemde } \\
\text { Bekleyen }\end{array}$ & $\begin{array}{c}\text { Bankanın Talebi } \\
\text { Karşılaması Sonucunda } \\
\text { Gündemden Çıkarılan }\end{array}$ & $\begin{array}{l}\text { Müşteri Lehine } \\
\text { Karar Verilen }\end{array}$ & $\begin{array}{c}\text { Banka Lehine } \\
\text { Karar } \\
\text { Verilen } \\
\end{array}$ & $\begin{array}{l}\text { Müşteri Lehine } \\
\text { Sonuçlanma } \\
\text { Oranı } \\
\end{array}$ \\
\hline \multirow{6}{*}{$\begin{array}{l}\text { Banka ve Kredi } \\
\text { Kartları }\end{array}$} & 2012 & 1.060 & 195 & 19 & 635 & 93 & 55 & 63 \\
\hline & 2013 & 2.390 & 1.454 & 3 & 434 & 189 & 310 & 67 \\
\hline & 2014 & 5.303 & 2.733 & 0 & 1.055 & 318 & 1.197 & 53 \\
\hline & 2015 & 4.804 & 2.236 & 31 & 688 & 314 & 1.535 & 39 \\
\hline & 2016 & 4.209 & 1.552 & 30 & 676 & 551 & 1.400 & 46 \\
\hline & 2017 & 9.052 & 4.425 & 114 & 1.320 & 845 & 2.345 & 46 \\
\hline \multirow{6}{*}{ Tüketici Kredileri } & 2012 & 907 & 367 & 11 & 415 & 31 & 32 & 51 \\
\hline & 2013 & 1.764 & 1.418 & 6 & 72 & 122 & 146 & 57 \\
\hline & 2014 & 4.587 & 3.582 & 0 & 208 & 384 & 413 & 59 \\
\hline & 2015 & 1.770 & 1.324 & 1 & 75 & 120 & 250 & 44 \\
\hline & 2016 & 1.142 & 925 & 0 & 24 & 33 & 160 & 26 \\
\hline & 2017 & 2.024 & 1.792 & 4 & 18 & 41 & 169 & 25 \\
\hline \multirow{6}{*}{$\begin{array}{l}\text { Diğer Bankacilık Ürün } \\
\text { ve Hizmetleri }\end{array}$} & 2012 & 1.053 & 270 & 14 & 559 & 88 & 46 & 76 \\
\hline & 2013 & 2.119 & 1.626 & 6 & 206 & 123 & 158 & 68 \\
\hline & 2014 & 3.440 & 2.434 & 1 & 531 & 171 & 303 & 69 \\
\hline & 2015 & 2.733 & 1.578 & 6 & 355 & 375 & 419 & 64 \\
\hline & 2016 & 1.264 & 778 & 5 & 160 & 132 & 189 & 61 \\
\hline & 2017 & 2.218 & 1.531 & 15 & 136 & 86 & 450 & 32 \\
\hline \multirow{6}{*}{ Sigortacılık İşlemleri } & 2012 & 143 & 28 & 0 & 87 & 9 & 11 & 8 \\
\hline & 2013 & 237 & 177 & 0 & 19 & 12 & 29 & 52 \\
\hline & 2014 & 498 & 286 & 0 & 66 & 40 & 106 & 50 \\
\hline & 2015 & 298 & 176 & 2 & 26 & 27 & 67 & 44 \\
\hline & 2016 & 272 & 141 & 3 & 21 & 14 & 93 & 27 \\
\hline & 2017 & 634 & 428 & 15 & 29 & 26 & 136 & 26 \\
\hline \multicolumn{2}{|l|}{ Toplam } & 53.921 & 31.456 & 286 & 7.815 & 4.144 & 10.019 & - \\
\hline
\end{tabular}

Kaynak: Türkiye Bankalar Birliği, Bireysel Müşteri Hakem Heyeti Yıllık Faaliyet Raporu, (https://www.tbb.org.tr/tr, Erişim Tarihi: 02.08.2018) 


\section{TÜRKIYE'DE SIGGORTACILIK ISLEMLERINDEN DOĞAN UYUŞMAZLIKLARIN ÇÖZÜMÜNDE TAHKIM UYGULAMASI}

Bir finansal işlemin tarafları, aralarındaki anlaşmazlıkları alternatif olarak hakem tarafından çözmeyi kabul edebilir ve böylece anlaşmazlığa kamu karar vericilerinden ziyade özel olarak yargı yetkisi kazandırabilirler. Tahkim, dava masraflarını azaltma eğiliminde olduğu ticari ve sigorta anlaşmazlıklarının çözümünde uzun zamandır yaygın olarak kullanılmaktadır (Park, 1998: 215). Ülkemizde sigortacılık alanında özel ihtisas mahkemelerinin bulunmaması ve uyuşmazlıkların adliye mahkemelerinde oldukça uzun sürelerde çözümlenebilmesi sebebiyle sigorta yaptıran ve sigortalıların haklarını elde etmeleri zorlu uğraşı gerektirmektedir. Türkiye sigortacılık alanında Avrupa Birliği ve üye ülkelerin uzun süreden beri uyguladığı alternatif çözüm yolları uygulamasına geç adım atmıştır. Özellikle alternatif uyuşmazlık çözüm yöntemi olan "tahkim” mehaz Alman ve İsviçre uygulamasında bankacılık ve sigortacılık alanlarında kullanılmaya başlanmış ve uygulama 5684 sayılı Sigortacılık Kanunu ile Türk hukukuna "Sigorta Tahkim Sistemi" olarak girmiştir (Özdamar, 2013: 832-834).

Alternatif uyuşmazlık çözüm yöntemleri konusunda Türk Hukukunda önemli adımlar atılmaktadır. "Tüketici Hakem Heyetleri” bu konuda önemli bir yere sahip olmakla beraber, özel sigorta sözleşmelerine ilişkin ihtilaflarda Sigorta Tahkim Komisyonu sadece sigorta işlerine münhasır olarak faaliyet göstermektedir (Caner, 2014: 2533). Komisyon Başkanlığ1, bir Hazine Müsteşarlıği temsilcisi, iki Birlik temsilcisi, bir tüketici derneği temsilcisi ile Müsteşarlıkça belirlenecek bir akademisyen hukukçu temsilcinin katılımı ile oluşur (Sigorta Tahkim Komisyonu, 2018). Sigorta tahkim sistemi ile uyuşmazlıklar, adli yargı'ya göre çok daha kısa sürede ve çok daha ucuza çözümlenmesi mümkün olabilmektedir. Uygulamanın merkezinde sigorta tahkim komisyonu yer almakta ve komisyon bünyesinde sigortacilık alanında uzman ve uygun şekilde seçilmiş hakemler aracılığı ile sigorta ettirene ve sigortalıya adil ve hızlı bir çözüm sunulabilmektedir (Özdamar, 2013: 832-833). Şekil 2'de 2012-2017 yılları ve branş bazında hakem sayıları verilmektedir.

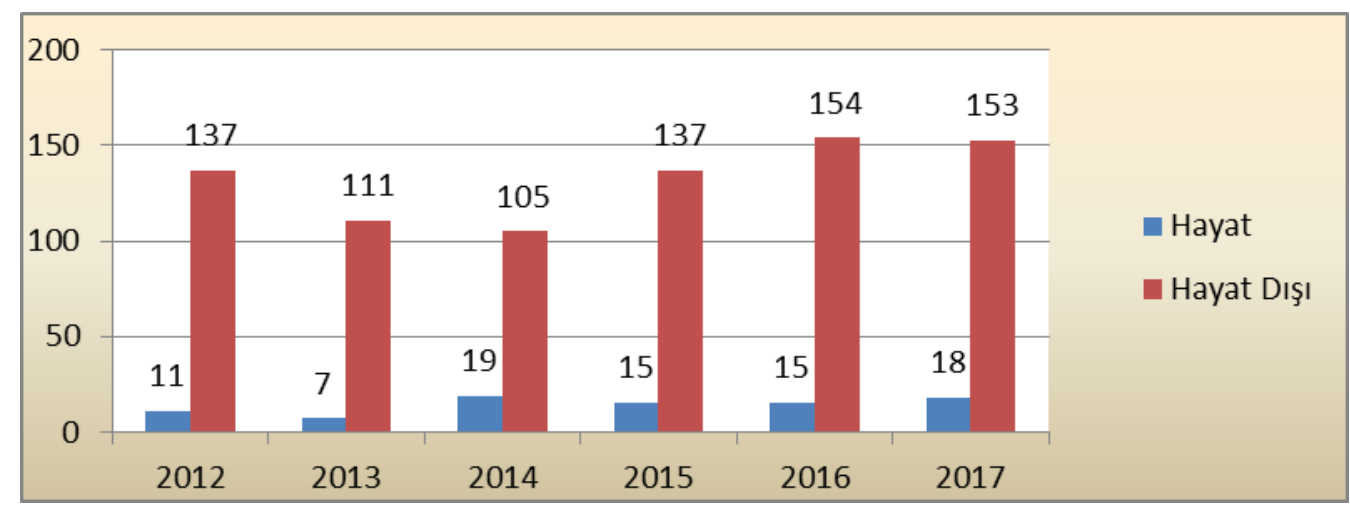

Kaynak: Sigorta Tahkim Komisyonu Faaliyet Raporu (http://www.sigortatahkim.org, Erişim Tarihi: 02.08.2018).

Şekil 2. 2012-2017 Yılları Branş Bazında Hakem Sayıları 
Türk Hukukunda tarafların anlaşamaması durumunda tahkim kararının verilmesinde süre uzatımı için mahkemeye başvurulması gerekmektedir. Hakem kararı süresinde verilmezse söz konusu kararların iptal edilebileceği, hatta tahkim şartının geçersiz hâle geleceği şeklinde son derece ağır yaptırımlar öngörülmüştür (Bacanlı, 2016: 87-88). Tahkim müessesesinde uyuşmazlıkların çözüme kavuşturulma süresi kural olarak mahkemelerdeki yargılamaya göre daha kısadır. Hakem veya hakemler ilk toplantı tarihinden itibaren 6 ay içinde karar vermek zorundadırlar. Tahkim sonunda verilen karara karşı kanun yolları da sınırlı olduğundan verilen hükmün kesinleşmesi ve icrası daha çabuk olabilmektedir (Dağlı ve Çakır, 2009: 33). Tahkim ile sigorta hukukunda ihtisas kazanmış, tarafsız ve bağımsız hakemler yargılama yapmakta; uyuşmazlıklar dört ay gibi kısa bir sürede çözüme kavuşmakta ve yargilama giderlerinde ciddi bir azalma sağlanmaktadır (Caner, 2014: 2531). Tablo 4'de 2012-2017 yılları arasında verilen hakem kararları ve uyuşmazlık çözüm süresine yer verilmektedir.

Tablo 4. 2012-2017 Yılları Arasında Verilen Hakem Kararları ve Uyuşmazlık Çözüm Süresi

\begin{tabular}{|c|c|c|c|c|c|c|c|}
\hline Yillar & $\begin{array}{l}\text { Adet } \\
\text { ve \% }\end{array}$ & $\begin{array}{l}\text { 0-30 } \\
\text { Gün }\end{array}$ & 31-60 Gün & $\begin{array}{c}\text { 61-90 } \\
\text { Gün }\end{array}$ & $\begin{array}{c}\text { 91-120 } \\
\text { Gün }\end{array}$ & Toplam & $\begin{array}{c}\text { Ortalama } \\
\text { Çözüm Süresi }\end{array}$ \\
\hline \multirow{2}{*}{2012} & Adet & 453 & 307 & 278 & 492 & 1530 & \multirow{2}{*}{62 Gün } \\
\hline & $\%$ & 30 & 20 & 18 & 32 & 100 & \\
\hline \multirow{2}{*}{2013} & Adet & 768 & 559 & 588 & 847 & 2762 & \multirow{2}{*}{62 Gün } \\
\hline & $\%$ & 28 & 20 & 21 & 31 & 100 & \\
\hline \multirow{2}{*}{2014} & Adet & 1451 & 1142 & 932 & 1388 & 4913 & \multirow{2}{*}{63 Gün } \\
\hline & $\%$ & 30 & 23 & 19 & 28 & 100 & \\
\hline \multirow{2}{*}{2015} & Adet & 3557 & 3883 & 3454 & 4718 & 15612 & \multirow{2}{*}{63 Gün } \\
\hline & $\%$ & 23 & 25 & 22 & 30 & 100 & \\
\hline \multirow{2}{*}{2016} & Adet & 8.180 & 9.847 & 7.642 & 12.314 & 37.983 & \multirow{2}{*}{44 Gün } \\
\hline & $\%$ & 22 & 26 & 20 & 32 & 100 & \\
\hline \multirow{2}{*}{2017} & Adet & 16.977 & 17.178 & 11.523 & 19.202 & 64.880 & \multirow{2}{*}{63 Gün } \\
\hline & $\%$ & 26 & 26 & 18 & 30 & 100 & \\
\hline
\end{tabular}

Kaynak: Sigorta Tahkim Komisyonu Faaliyet Raporu (http://www.sigortatahkim.org, Erişim Tarihi: 02.08.2018)

Tahkim yargılamasında ücretler, hakem ücretleri, bilirkişi ve keşif ücretleri, yargılama giderleri vb. masraflardan oluşmaktadır. Hakem ücretleri, Hukuk Usulü Muhakemeleri Kanunu'na (HUMK) göre taraflar arasında serbestçe kararlaştırılabildiği gibi, dava sonuçlandıktan sonra yetkili hâkim tarafından davanın değeri ve hakemlerin uyuşmazlığı çözmekteki çabası göz önünde bulundurularak da belirlenebilmektedir (Dağlı ve Çakır, 2009: 33-34). Tablo 5'de hakem ücretinin hesaplanmasına yer verilmektedir. 
Tablo 5. Hakem Ücretinin Hesaplanmas1

\begin{tabular}{|c|c|c|}
\hline $\begin{array}{c}\text { Uyuşmazlık Konusu Değer } \\
\text { (TL) }\end{array}$ & $\begin{array}{c}\text { Tek } \\
\text { Hakem için }\end{array}$ & $\begin{array}{c}\text { Üç Veya Daha Fazla } \\
\text { Sayıda Hakem için }\end{array}$ \\
\hline $0-14.999$ & $3 \%$ & $9 \%$ \\
\hline 15.000 ve üzeri & - & $6 \%$ \\
\hline
\end{tabular}

Türkiye'de miktar yönünden küçük olan uyuşmazlıkların gerek maliyeti gerekse yargılamanın uzun sürmesi nedeniyle yargıya taşınmadığı gözlenmektedir. Bu durumda zaten sigorta şirketi karşısında zayıf konumda bulunan sigorta ettiren/sigortalının hakkını aramasının zorlaşması, sigorta sözleşmesinin tarafları arasındaki dengeyi daha da bozmaktadır. Türkiye'de tahkim sayesinde sigortacılık sektöründe meydana gelen uyuşmazlıkların kısa zamanda ve güvenilir bir şekilde çözümlenmesi mümkün olmaktadır. Tahkim usulünde hakem ya da hakem heyeti tarafindan verilen kararların çoğu kesin olmasının yanı sıra diğer uyuşmazlıklar içinde örnek oluşturmaktadır (Özdamar, 2013: 831832). Tablo 6'da 2012-2017 yılları arasında Sigorta Tahkim Komisyonuna Başvuruların Uyuşmazlık Miktarı Bazında Dağılımı verilmektedir. Tablo 6'de tüm yıllar için uyuşmazlıkların \% 70'inden fazlasının 0-15.000 TL olduğu görülmektedir.

Tablo 6. Başvuruların 2012-2017 Yıllarında Uyuşmazlık Miktarı Bazında Dağılımı

\begin{tabular}{|l|c|c|c|c|c|c|c|c|c|c|c|c|}
\hline \multicolumn{1}{|c|}{ Miktar } & \multicolumn{2}{c|}{$\mathbf{2 0 1 2}$} & \multicolumn{2}{c|}{$\mathbf{2 0 1 3}$} & \multicolumn{2}{c|}{$\mathbf{2 0 1 4}$} & \multicolumn{2}{c|}{$\mathbf{2 0 1 5}$} & \multicolumn{2}{c|}{$\mathbf{2 0 1 6}$} & \multicolumn{2}{c|}{$\mathbf{2 0 1 7}$} \\
\hline TL & Adet & $\mathbf{\%}$ & Adet & $\mathbf{\%}$ & Adet & $\mathbf{\%}$ & Adet & \% & Adet & \% & Adet & \% \\
\hline $0-5.000$ & 1.225 & 52,06 & 2.096 & 48,5 & 6.573 & 61,48 & 17.241 & 66,21 & 30.972 & 73,69 & 64.964 & 76,92 \\
\hline $5.001-15.000$ & 528 & 22,44 & 936 & 21,66 & 1086 & 10,16 & 5221 & 20,05 & 5.698 & 13,56 & 4.370 & 11,5 \\
\hline $15.001-40.000$ & 354 & 15,04 & 591 & 13,67 & 926 & 8,66 & 1.588 & 6,1 & 2.390 & 5,69 & 5.411 & 5,17 \\
\hline $40001-$ & 246 & 10,45 & 699 & 16,17 & 2107 & 19,71 & 1.989 & 7,64 & 2.969 & 7,06 & 7.711 & 6,41 \\
\hline Toplam & 2353 & 100 & 4321 & 100 & 10692 & 100 & 26.039 & 100 & 42.029 & 100 & 84.456 & 100 \\
\hline
\end{tabular}

Kaynak: Sigorta Tahkim Komisyonu Faaliyet Raporu (http://www.sigortatahkim.org,(Erişim Tarihi: 02.08.2018)

Sigorta tahkim sistemi, ülkemizde doğrudan Sigorta ve Reasürans Şirketleri Birliğine bağlı olarak kurulan ve ayrı tüzel kişiliği bulunmayan Sigorta Tahkim Komisyonu bünyesinde kurulmuştur (SK m. 30/1). Sigortacının tahkim sistemine üye olması zorunlu değildir, ancak ülkemizde faaliyet gösteren sigortacıların büyük çoğunluğu sigorta tahkimine üye olmuş ve tahkim komisyonunun yetkisini kabul etmişlerdir (Özdamar, 2013: 845). Tablo 7 'de sigorta tahkim komisyonuna başvuruların 2012-2017 yıllarında branş bazında dağılımı verilmektedir. 
Tablo 7. Sigorta Tahkim Komisyonuna Başvuruların 2012-2017 Yı1larında Branş Bazında Dağılımı

\begin{tabular}{|c|c|c|c|c|c|}
\hline Yll & Hayat & \% & Hayat Dışı & \% & Toplam \\
\hline 2012 & 138 & 5,86 & 2215 & 94,14 & 2.353 \\
\hline 2013 & 277 & 6,41 & 4045 & 93,59 & 4.322 \\
\hline 2014 & 386 & 3,61 & 10.306 & 96,39 & 10.692 \\
\hline 2015 & 353 & 1,36 & 25686 & 98,64 & 26.039 \\
\hline 2016 & 273 & 0,72 & 41.756 & 99,28 & 42.029 \\
\hline 2017 & 462 & 0,55 & 83.994 & 99,45 & 84.456 \\
\hline
\end{tabular}

Kaynak : Sigorta Tahkim Komisyonu Faaliyet Raporu (http://www.sigortatahkim.org., Erişim Tarihi: 02.08.2018)

Mahkemelerde özel ve teknik bilgiyi gerektiren bir uyuşmazlığın varlığı halinde hâkimin uyuşmazlıkla ilgili bilirkişiye başvurması zaman kaybı ve masrafa neden olmaktadır. Özellikle bilirkişi raporuna yapılan itirazlar ve bilirkişiye birkaç kez başvurulması süreci daha da uzatmaktadır. Uyuşmazlığın tahkim yolu ile çözümlenmesinde hakemlerden bir veya bir kaçının teknik ve özel konuda bilgi sahibi olması durumunda zaman ve kaynak kaybı olmamaktadır ${ }^{6}$. Diğer taraftan teknik bilgiye sahip olan hakemler hukuki bilgiye sahip olmamaları bu durumun olumsuz yönünü oluşturmaktadır (Dağlı ve Çakır, 2009: 33).

\section{SONUÇ}

Özellikle ABD ve birçok Avrupa ülkesinde alternatif uyuşmazlık çözüm yöntemlerinin yoğun olarak kullanılması, ülkemizde olduğu gibi tutarı düşük olan konularda uyuşmazlık sahiplerinin mahkemelerin uzun süren ve yorucu yargılama süreçlerine girmek istemediği, dolayısı ile haksızlığa uğrayan tarafın hakkını hukuki yollarla veya hiç arayamadığı bir durumla kıyaslandığında tahkim kurumuna olan ihtiyaç daha açık anlaşılabilecektir. Tahkim yargılama süresinin kısa olması, maliyetinin düşük olması, tarafların gizlilik taleplerine olumlu cevap verilmesi gibi avantajları karşısında bazı hukukçuların çift başlı bir hukuk uygulamasının adalet sistemine zarar verebileceği, tahkimin kısa sürede ve düşük maliyetle çözümlenmesi konusunda devlet mahkemelerine gelen dava taleplerine oranla tahkim müessesesine sınırlı sayıda uyuşmazlığın gelmesi, tahkim kararlarının ne düzeyde adil olduğuna ve tarafları memnun ettiğine dair bilginin olmaması

\footnotetext{
6 "Dava, hakem heyeti kararının iptali istemine ilişkin olup, hakem heyeti kararlarının iptalini düzenleyen 6100 sayılı HMK'nın 439. maddesinde hangi şartlarda hakem kararlarının iptal edilebileceği dokuz bent halinde sayılmıştır. Davacı vekili iddialarını HMK'nın 439/2-b.ç.d.e. .g. bentlerine dayandırmış, mahkemece 439/2-e. $\breve{g}$. bentlerindeki koşulların gerçekleşmiş olduğu, hakem heyetinin uzmanlığı olmadığı halde tazminat hesabı yaptığı, bunun yerine bilirkişiden rapor alması gerektiği ve davacının mahvına yol açabilecek miktardaki tazminattan BK 162/son fikrası uyarınca tenkis yapılabileceğinin dikkate alınmadığı gerekçeleriyle hakem kararının iptaline karar verilmiştir. Taraflar arasındaki sözleşmeyle aralarında çıkacak uyuşmazlıkların hakem heyeti kararıyla çözüleceği kararlaştırılmış, buna göre oluşturulan üç kişilik hakem heyeti incelemeleri sonucunda bir karara varmıştır. Hakem heyeti, süreci yürütürken bilirkişiden rapor alıp almamakta takdir hakkına sahip olduğu gibi, uygulanacak hukuk kurallarının tespiti ve tahlili de hakem heyetine aittir. Hakem heyeti kararının esası, yerinde olup olmadığı, hukuku doğru uygulayıp uygulamadığı gibi hususlar hakem heyeti kararının iptali istemli davada tartışma konusu yapılamayacak olup, mahkemece bu nedenlerle davanın reddi gerekirken hakem heyetinin takdirine ve kararının esasına yönelik değerlendirilmeler yapılması doğru olmamış, bozmayı gerektirmiştir”. (Yargıtay 11. H.D.'nin 22.06.2016 Tarih, 2016/4931 Esas ve 2016/6886 Karar Sayılı İlami).
} 
gibi konularda eleştiriler bulunmaktadır. Tablo 3'de Türkiye Bankalar Birliği bireysel müşteri hakem heyetinde gündeme alınan başvuruların müşteri lehine sonuçlanma oranının banka ve kredi kartları dışında yıllar itibariyle düşmesi, devlet mahkemeleri yargılamasında olduğu gibi hakem veya hakem heyetleri kararlarının da denetime açık olması gereğini göstermektedir.

Yasama organları, tüketicileri ciddi şekilde korumak isteyip istemediğine karar vermelidir. ADR türleri bireysel şikayetçiyi izole ederek ve anlaşmazlığı hızlı ve ucuz bir şekilde çözerek yaparlar. Bununla birlikte, ADR uygulamaları, pek çok tüketici şikayetinin sebebi olan altta yatan sorunu çözmek için bir şey yapmamaktadır. Bugün çoğu tüketici sözleşmesinin konusunu oluşturan belirli mal ve hizmet satımı ya da kiralamasında tahkim şartına yer verildiği görülmekte ancak tüketicilerin ticari işletmelerle yaptıkları sözleşmelerde çoğu zaman sözleşmenin bir tahkim şartı içerip içermediğine dikkat etmemekte veya ortalama dikkate sahip bir tüketici, tahkim şartının dilini dahi anlamayabilmektedir. Tahkim müessesesinin başarılı uygulamalarını ve gelişmesini sağlayacak düzenlemeler yapılırken tahkime yöneltilen tüm bu eleştiriler ve çekincelerin haklı olduğu yönlerin de göz önünde bulundurulması gerekmektedir.

Çalışmamızda ulaşılan en belirgin sonuç TBB bünyesinde kurulan Bireysel Müşteri Hakem Heyeti'ne 2014 yılından itibaren krediler, banka ve kredi kartları, sigorta işlemleri, mevduat işlemleri, fatura ve diğer ödemelerle ilgili yapılan başvuru sayısı devamlı azalmaktadır. Hakem Heyeti'nin başvuruları müşteri lehine sonuçlandırma oranları da 2014 yılından itibaren sürekli azalmaktadır. Sigorta Tahkim Komisyonu'na olan başvurular ise 2012 yılından 2017 yılına kadar devamlı artış göstermiştir. Bu sonuçlar incelendiğinde Hakem heyetlerinin oluşma biçimi, heyet üyelerinin eğitim düzeyleri, kararlarında adil olmasını gerektirecek şekilde tarafsız ve bağımsız olup olmadıkları, hukuki ve teknik olarak yeterli bilgiye sahip olup olmadıklarının yanı sıra tüketicilerin finansal okuryazarlık düzeylerinin birlikte ele alınarak incelenmesi gerekmektedir. Diğer türlü bazı alanlardaki başarılı uygulamalarına rağmen bazı adalet uygulayıcılarının tahkim ile ilgili bahsedilen eleştiri ve endişelerinin haklı olduğu yönünde görüşler oluşabilmektedir.

Mahkemelerde görülen dava sayısının her geçen gün artması, uyuşmazlıkların çözüm süresini uzatmakla kalmamış, aynı zamanda yargılama giderlerinin, uyuşmazlık konusunun değeriyle orantısız ölçüde artmasına da yol açmıştır. Bunun sonucunda Avrupa Birliğine üye devletler dava yolu dışında uyuşmazlık çözüm usûllerinin arayışına yönelmişlerdir. Kuzey Amerika'da çok yaygın olan ADR, Avrupa Birliği üyesi ülkelerde özellikle bireylerle idare arasındaki uyuşmazlıklarda, ticarî ilişkilerden doğan uyuşmazlıklarda, tüketici hukuku, aile hukuku, iş hukukundan doğan uyuşmazlıklarda giderek yaygınlaşmıştır. Ülkemizde de adalet hizmetlerinin etkinliğini artırmak amacıyla, Avrupa Birliği kanunlarına uyum sağlamak için yürütülen çalışmalar kapsamında, ADR ile ilgili yasal düzenlemeler yapılmaktadır.

İstanbul Finans Merkezi projesinde finans ve ekonominin yoğunlaştığı başta İstanbul olmak üzere büyük şehirlerde finansal ve ekonomik uyuşmazlıkların çözümü için ihtisaslaşmış mahkemelerde sermaye piyasası, ticaret hukuku, bankacılık hukuku, sigortacılık hukuku alanlarında ihtisaslaşmış hâkimlerin yetiştirilmesi ve mahkemelerin oluşturulması finans alanındaki uyuşmazlıkların hızlı, doğru ve etkin bir şekilde çözümlenmesini sağlayacaktır. Finansal uyuşmazlıklarda tahkim uygulaması ile ilgili konu bazında, bölge ve il bazında tahkim uygulama verileri, sonuç bakımından dava açılıp açılmadığı ile ilgili bir veriye ulaşılabilecek kamuya ait veya İstanbul tahkim merkezi tarafindan tutulan bir istatistik 
bulunmamaktadır. İlgili istatistiklerin tutulmasıyla banka ve sigorta şirketlerinin işlemlerinden kaynaklı uyuşmazlıkların çözümünde tahkim kurumunun işlevselliği hakkında yapılabilecek değerlendirmeler ve akademik çalışmalara veri sağlanması mümkün olabilecek ve böylece Türk finans uyuşmazlıklarında tahkimin uygulama başarısı, uygulanabilirliği ve geliştirilmesi gereken adımlar konusunda daha sağlam temeller atılabilecektir.

\section{KAYNAKLAR}

Akıncı, Ziya (2013), "Neden İstanbul Tahkim Merkezi?", Yaşar Üniversitesi Dergisi, ss.7996.

Aksoy, Barış- Koç, Selahattin- Boztosun, Derviş. (2017), "Analysis of Mediation Practices in the Solution of Financial Disputes in Turkey", International Journal of Social Sciences and Education Research, 3 (5), pp.1868-1880.

Baykal, C. Murat (2008), "Hukuk-Ekonomi İlişkisi ve Ekonomi Hukuku Üzerine", Ankara Barosu Dergisi, 4, ss. 76-87.

Bacanlı, Mehmet Rıfat (2016), "Bir Alternatif Uyuşmazlık Çözüm Yolu Olarak İstanbul Tahkim ve Arabuluculuk Merkezi (ISTAC) Tahkim Yargılamasında Delillerin İbrazı ve Değerlendirilmesi", Uyuşmazlık Mahkemesi Dergisi, ss.75-113.

Budnitz, Mark E. (1995), "Arbitration of Disputes Between Consumers and Financial Institutions: A Serious Threat to Consumer Protection", Ohio State Journal on Dispute Resolution, 10(2), pp.267-342.

Bulur, Alper (2007), "Alternatif Uyuşmazlık Çözüm Yolları ve Arabuluculuk Yöntemi", Ankara Barosu Dergisi , 4, ss.30-46.

Caner, Oğuz (2014), 6502 Sayılı Tüketicinin Korunması Hakkında Kanunun Özel Sigorta Sözleşmelerine Etkisi , Prof. Dr. Feridun Yenisey'e Armağan Cilt II, İstanbul: Beta Basım Yayınları. ss. 2501-2534.

Dağlı, M. Kubilay- Çakır, Yasemin (2009), "Türk Sermaye Piyasasında Tahkim Uygulaması ve Etkinleştirilmesine Yönelik Öneriler", Sayıştay Dergisi, Sayı 72, ss.27-50.

Golann, Dwight. (1989), "Taking ADR to the Bank: Arbitration and Mediation in Financial Services Disputes", The Arbitration Journal , pp.3-14.

Gündoğdu, Aysel- Dizman, Arzu Seçil (2013), "İstanbul Finans Merkezi Projesinin SWOT Analizi ile Değerlendirilmesi ve Dünya Finans Merkezleri ile Kiyaslanması", Ekonomi Bilimleri Dergisi,1,ss. 1-15.

Kayıhan, Şaban- Eski, Mehmet (2015), "Uluslararası Ekonomi Hukuku Kavramı ve Uluslararası Ekonomi Hukukunun Kaynakları", International Conference on Eurasian Economies. Kazan: Eurasian Economists Association, ss. 591-600.

Özbek, Mustafa (2007), "Avrupa Birliğinde Alternatif Uyuşmazlık Çözümü", Türkiye Barolar Birliği Dergisi , 68, ss.265-320. 
Özdamar, Mehmet (2013), "Sigorta Hukukunda Uyuşmazlıkların Çözümünde Tahkim Sistemi", Gazi Üniversitesi Hukuk Fakültesi Dergisi, 17, ss.831-855.

Park, William W. (1998), "Arbitration in Banking and Finance", Annual Review of Bankıng Law, 17, 2pp.13-285.

Perçin, Gizem Ersen (2011), "Alternatif Uyuşmazlık Çözüm Yöntemlerinden Arabuluculuğun Hukuksal Düzenlemelerdeki Yeri", Milletlerarası Hukuk ve Milletlerarası Özel Hukuk Bülteni, 2, ss.177-201.

Petrauskas, Feliksas- Gasiūnaite, Aida (2012), "Alternative Dispute Resolution in The Field of Consumer Financial Service", Jurisprudence, pp.179-194.

Scarpino, Julia A. (2002), "Mandatory Arbitration of Consumer Disputes: A Proposal to Ease the Financial Burden on Low-Income Consumers", Journal Of Gender, Social Policy \& The Law, 10(3), pp.680-710.

Şahin, İlhan (2013), "İstanbul'un Küresel Finans Merkezi Olması Projesinin Ülke Örnekleri ve SWOT Analizi ile Değerlendirilmesi", TİSK Akademi, 2, ss.134-169.

Tanrıver, Süha (2006), "Hukuk Uyuşmazlıkları Bağlamında Alternatif Uyuşmazlık Çözüm Yolları ve Özellikle Arabuluculuk", Türkiye Barolar Birliği Dergisi, 64, ss.151-177.

Ulusoy, Erol (2014), Finans Hukukunda Tahkim. II. Uluslararası Özel Hukuk Sempozyumu "TAHKİM" İstanbul : Marmara Üniversitesi Hukuk Fakültesi , ss. 203-251.

Uyumaz, Alper- Akdağ, İdris (2016), "Bankacılık Faaliyetlerinde Tüketicinin Korunması Açısından Hukuka Aykırı Alınan Ücret ve Masraflar ile Bunların İadesi", İstanbul Üniversitesi Hukuk Fakültesi Mecmuası, 74, ss.423-459.

Yanase, Shuji (2013), "The Standards of Judgment For Dispute Resolution in Financial ADR of Japan", Columbia Journal of Asian Law, 26, pp.29-104.

Zhu, Weidong (2013), "Arbitration as the Best Option for the Settlement of China-African Trade and Investment Disputes", Journal of African Law, 57, pp.149-163.

İstanbul Uluslararası Finans Merkezi Eylem Planı, http://www.sgb.adalet.gov.tr

(05 08. 2017)

Sigorta Tahkim Komisyonu, http://www.sigortatahkim.org, ( 08. 07.2018)

Türkiye Bankalar Birliği, http://www.tbb.org.tr (06. 11. 2017)

Türkiye Cumhuriyeti Adalet Bakanlığı Adli Sicil ve İstatistik Genel Müdürlügüu, http://www.adlisicil.adalet.gov.tr , (06. 10.2017) 
